\title{
Do heavy-metal grassland species survive under a Scots pine canopy during early stages of secondary succession?
}

\author{
Pawel Kapusta • Grażyna Szarek-Lukaszewska • \\ Monika Jędrzejczyk-Korycińska • Monika Zagórna
}

Received: 21 February 2015 / Accepted: 12 October 2015 / Published online: 23 November 2015

(C) The Author(s) 2015. This article is published with open access at Springerlink.com

\begin{abstract}
The highly specialized flora of localities affected by former metal ore mining and metallurgy is endangered by succession or intentional afforestation all over Europe. Its last remnants therefore deserve our attention. We examined whether Scots pine encroaching on a heavy-metal grassland (Olkusz Zn-Pb mining area, $\mathrm{S}$ Poland) is outcompeting specialized herbaceous species, as has been observed elsewhere. Plant species composition and richness sampled at 124 plots were analysed in relation to pine stand parameters (canopy cover, stand age, stand basal area), abiotic environmental factors (e.g. soil properties) and spatial variables (e.g. plot coordinates). Plots were divided into three shading categories and compared in terms of vegetation and habitat parameters. Scots pine outcompeted several light-demanding species, leading to a decrease of total species richness and cover. Characteristic species of this grassland (Biscutella laevigata, Silene vulgaris) and some metal-tolerant plants were clearly insensitive to shading. For these early successional species, more important was the availability of microsites with shallow skeletal soil or bare subsoil. Tree stand parameters differently affected grassland vegetation: canopy cover
\end{abstract}

Plant nomenclature Mirek et al. (2002)

P. Kapusta $(\bowtie) \cdot G$. Szarek-Łukaszewska

W. Szafer Institute of Botany, Polish Academy of Sciences, 46

Lubicz St., 31-512 Kraków, Poland

e-mail: p.kapusta@botany.pl

M. Jędrzejczyk-Korycińska • M. Zagórna

Department of Botany and Nature Protection, University of

Silesia, 28 Jagiellońska St., 40-032 Katowice, Poland caused primarily a compositional shift in the community, while stand age was the principal agent of decline in species richness. Scots pine increased the soil concentrations of available $\mathrm{Ca}$ and $\mathrm{Mg}$, and negatively affected soil development (organic matter and mineral particle accumulation), which might be beneficial to some shade-tolerant grassland species. Maintaining the studied grassland's present species richness and composition would require cutting woody plants less frequently than recommended for dry grasslands of non-metalliferous sites, and disturbing the soil surface.

Keywords Community structure $\cdot$ heavy-metal grassland · metalliferous soil · Pinus sylvestris . secondary succession $\cdot$ Variation partitioning

\section{Introduction}

Metalliferous sites have recently become high-priority conservation targets in Europe (Baker et al. 2010; Baumbach 2012). They are cultural heritage sites associated with earlier metal ore mining and metallurgy. They are also, and primarily, localities of a highly specialized flora formed by plant species, subspecies and ecotypes that under strong selection pressure, have developed morphological, anatomical or physiological adaptations enabling them to survive in extremely hostile habitats (Shaw 1990; Baker et al. 2010; Baumbach 2012). These plants, known as metallophytes, withstand the high content and consequently high toxicity of 
heavy metals, and also survive under nutrient and water scarcity.

For plant ecologists, some of the most interesting metalliferous sites are those left after zinc, lead and copper mining. In Europe, these are localities of heavy-metal grassland of the Violetea calaminariae class (Ernst 1974). The most studied and most extensive patches of this kind of vegetation are located in a few countries: Belgium, Germany, the Netherlands and the United Kingdom (Baker et al. 2010). Similar plant communities occur in Poland as well; their range is limited to ore-bearing parts of the Silesian-Kraków Upland, especially the Olkusz Ore-Bearing Region (OOR). Endemic metallophytes and some characteristic species of heavymetal grasslands (e.g. Minuartia verna) are not noted there, but other equally interesting metal-tolerant taxa can be found (Grodzińska and Szarek-Łukaszewska 2009).

In the last few decades, metalliferous habitats have been consistently eliminated in the OOR, as in other parts of Europe (Baker et al. 2010). Considered a burdensome legacy of the metals industry and presumed to pose an environmental hazard, they have been developed, converted to municipal landfills, or subjected to afforestation, mainly with Scots pine (Pinus sylvestris).

Efforts to preserve the heavy-metal grassland in the OOR have led to its designation as a valuable remnant of this type of vegetation; a fragment covering a nonreclaimed mine spoil heap is on the list of Poland's protected areas. The protection programme for the grassland has not provided for any specific form of ecological management to prevent natural succession. There is some evidence, including literature reports and archival photographs (Wóycicki 1913; Dobrzańska 1955), that the spoil heaps in the Olkusz environs were not colonized by woody plants for a number of decades. The reason for this was thought to be the impact of heavy metals, which can be more toxic to long-lived plants (shrubs and trees) than to short-lived ones (Dickinson et al. 1991). Observations in recent years have challenged this idea. The heavy metals in the soil have not been toxic enough to harm Scots pine, which has proved to be highly resistant to such pollution, probably thanks to ectomycorrhizal associations (Colpaert et al. 2011). As dust and $\mathrm{SO}_{2}$ emissions from a nearby smelter were significantly reduced (Danek 2007), Scots pine began to rapidly colonize the majority of open areas, even heavily contaminated ones. Pine dispersal is now a relentless process which, without human intervention, may cause the OOR heavy-metal flora to decline.

In this study, we sought to find out whether, and if so how, the Scots pine encroaching on a heavy-metal grassland is outcompeting its many herbaceous species, leading to an overall decrease in species richness, as has been shown for grasslands on non-metalliferous soils (e.g. Rejmének and Rosén 1992; Davies and Waite 1998; Willems and Bik 1998). Are there any grassland species able to persist under pine canopy? Are metaltolerant taxa among them? Which pine stand parameters are most influential? Do pine trees exert an effect only by shading or also by altering soil conditions? To answer these questions, we recorded the species richness and composition of vascular plants of a heavy-metal grassland in a large number of plots varying in their level of shading by pine trees. In the plots, we also measured several environmental variables, including pine stand parameters, in order to capture all factors relevant to the distribution of herbaceous species. Since the plant community under study was expected to be spatially structured, we incorporated additional predictors: spatial variables derived from the spatial coordinates of the plots. Using variation partitioning, we assessed the relative contributions of three datasets (pine stand, abiotic environment, space) to the variation of species richness and composition.

\section{Material and Methods}

\section{Study Site}

The study site is a spoil heap of calcareous gangue more than a century old, remaining from $\mathrm{Zn}-\mathrm{Pb}$ ore extraction and processing. It is located near the town of Bolesław in the OOR, S Poland (19'28'21" E, 50 17'31" N). According to Grodzińska and Szarek-Łukaszewska (2009), the shallow rendzina-like soil on the heap contains $0.32-0.65 \% \mathrm{~Pb}$ and $3.3-7.8 \% \mathrm{Zn}$. Since $1997 \mathrm{ca}$ 5 ha of the heap has been under legal protection as an ecological area and a Natura 2000 site known as Pleszczotka górska. It is a stretch of species-rich heavy-metal grassland with abundant populations of rare plants, especially Biscutella laevigata and Gentianella germanica. Over the last three decades, this site has been colonized by Scots pine. The process accelerated in the late 1990s. In the year of the study, 
there were still patches of well preserved grassland vegetation there, not shaded by trees.

\section{Field Sampling}

In 2008, 124 circular plots $\left(1 \mathrm{~m}^{2}\right.$ each) were established on a grid at $8 \mathrm{~m}$ intervals in the study area (Fig. 1). The grid interval was chosen arbitrarily to provide a reasonable number of samples and to minimize autocorrelation resulting from the tree effect (a given tree could not shade more than one study plot). Two topographic variables were measured at each study plot: slope (with a SUUNTO PM-5/1520 clinometer) and aspect (with a compass).

During the vegetation season, the study plots were repeatedly surveyed to determine their vascular plant species composition. Plant species were identified in the field or sampled for identification in the laboratory. The abundance of particular species in the herb layer was estimated on a modified Braun-Blanquet scale (OTV scale) with nine degrees of cover (van der Maarel 2005). Supplementary data on the overall cover of lichens and bryophytes were also recorded.

After careful removal of the top soil organic layer (when present), four soil samples of the top mineral soil horizon were collected with a split corer $(10 \mathrm{~cm}$ deep, $3.5 \mathrm{~cm}$ in diameter) from each study plot and bulked into one composite sample. Those samples were taken from spots very near but not inside the plots, so as not to disturb the plot vegetation. These spots were also used to determine the thickness of the A horizon (mean of four measurements).
Three parameters describing the impact of pine were recorded for the study area: canopy cover, stand basal area and age. Canopy cover was estimated directly for each study plot on a three-point scale: 0 - open (exposed to direct sunlight), 0.5 - partially shaded (less than half of a plot shaded by pine branches) and 1 - deeply shaded (more than half of a plot shaded by pine branches). The latter two parameters were measured for 141 squares demarcated on the same grid of plots (Fig. 1). This was done in 2010 as part of another study (unpubl.). Stand basal area was calculated from tree diameter measured at breast height $(1.3 \mathrm{~m})$. Trees less than $1.3 \mathrm{~m}$ tall were not included in that calculation. The age of the pine trees was estimated by counting whorls of horizontal branches and then averaged for a grid square.

\section{Soil Analysis}

The composite fresh soil samples were sieved through $2 \mathrm{~mm}$ mesh and air-dried at room temperature. The fine fraction $(<2 \mathrm{~mm})$ was weighed and expressed as the percentage of soil sample total dry weight. Soil suspension $\mathrm{pH}$ was measured electrometrically using a $\mathrm{pH}$ electrode following extraction with $\mathrm{H}_{2} \mathrm{O}$ (1:5 w:v). Total nitrogen was determined by the Kjeldahl method (ISO 1995). The soil was digested in $\mathrm{H}_{2} \mathrm{SO}_{4}$ with Kjeltabs $\left(\mathrm{K}_{2} \mathrm{SO}_{4}+\mathrm{CuSO}_{4} \cdot 5 \mathrm{H}_{2} \mathrm{O}\right.$; Foss Tecator Digestor Auto) followed by distillation in a Foss Tecator Kjeltec 2300 Analyser Unit. Available (Olsen) phosphorus was measured with an ion chromatograph (Dionex ICS-1100) following extraction of soil with a

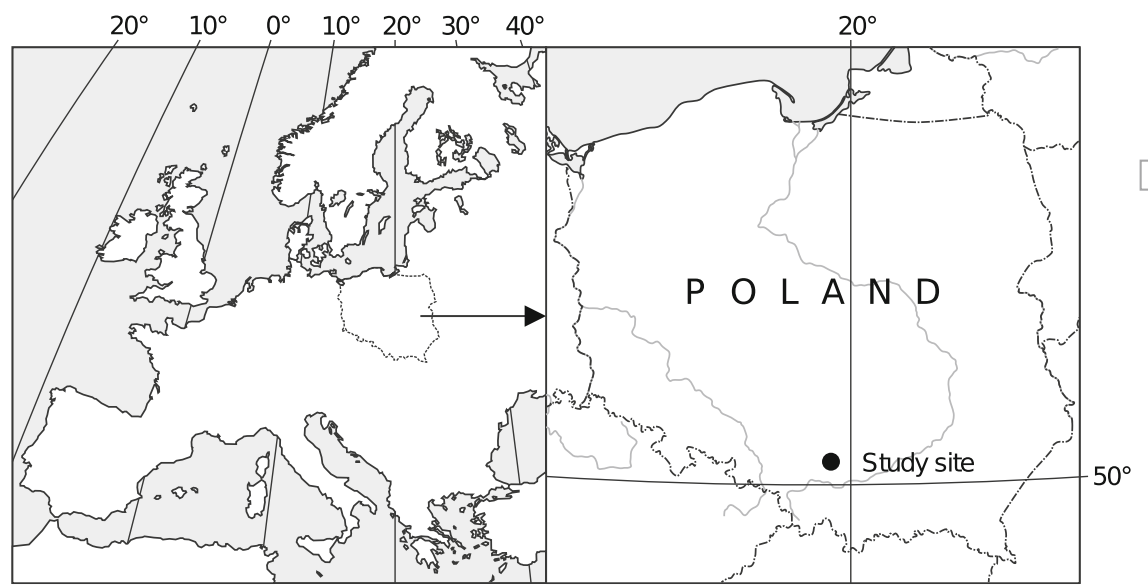

Fig. 1 a - Location of the study site, $\mathbf{b}$ - sampling grids applied in the study. b

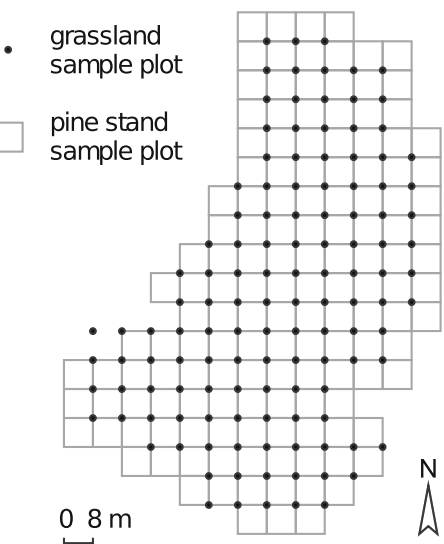


0.5 $\mathrm{M} \mathrm{NaHCO}_{3}, \mathrm{pH} 8.5$ (Olsen and Sommers 1982). The content of available $\mathrm{K}, \mathrm{Ca}, \mathrm{Mg}$ and $\mathrm{Zn}$ was determined by flame atomic absorption spectrometry (AAS, Varian 220 FS) after extraction with deionized water (1:10 w:v, samples shaken for $1 \mathrm{~h}$ ) for water-soluble or with $0.1 \mathrm{M} \mathrm{BaCl}_{2}$ at $\mathrm{pH} 7$ for exchangeable (ISO 1994). The availability of $\mathrm{Pb}$ (another important heavy metal in the OOR) was not analysed, since this element is largely immobilized in soils developed on calcareous mining spoils (Kapusta et al. 2011).

\section{Data Handling}

Based on the floristic data collected in the field, plant species richness (total number of herbaceous species) and cover were determined for each study plot. Cover was calculated by summing the percentage cover of individual species.

For each plot the slope-aspect index (SAI) was derived from topographic variables, calculated according to the formula of Nielsen et al. (2004): $\mathrm{SAI}=\sin (\operatorname{aspect}+225) \times($ slope $/ 46)$. The index represents the amount of direct solar radiation and warming of a plot in relation to a flat surface. The scale of this measure runs from -1 for the combination of highest slope ( $46^{\circ}$ in this study) and northeast aspect to +1 for the combination of highest slope and southwest aspect. SAI was used for statistical analysis instead of the original topographic variables.

The centres of the squares in which pine trees were measured did not fit the coordinates of the study plots. Therefore, the values for pine stand basal area and age had to be interpolated. This was done by ordinary kriging (Isaaks and Srivastava 1990). The pine variables were detrended before kriging, and their spatial dependence was modelled with a spherical function (variogram). After kriging, the spatial trends were added back to interpolated surfaces, and new values of the variables were extracted at the nodes of the study plot grid. Spatial analysis was performed with Surfer 8 (Golden Software Inc., Golden, CO, USA).

Exploratory spatial analysis (spatial correlograms) showed that both the response variables and explanatory variables were more or less spatially structured. The presence of spatial autocorrelation in the data complicates statistical testing because the assumption of independence of error terms is violated (Legendre et al. 2002). One method of dealing with this problem is to incorporate additional variables representing a variety of spatial patterns into the explanatory dataset. In this study, we used the raw coordinates of the plots (X, Y) and principal coordinates of neighbour matrices (PCNM), which are eigenvector-based spatial functions (Dray et al. 2006). The former represented linear trends in the data, and the latter modelled more complicated spatial structures - orthogonal (linearly independent) wavy structures covering all spatial scales encompassed by the sampling scheme (Borcard et al. 2011). A total of 88 PCNMs were generated (using R PCNM), 62 of which, characterized by positive spatial autocorrelation, were selected for subsequent analysis. Negative spatial autocorrelation was not taken into consideration. It is usually associated with small-scale structures produced by biotic processes such as species territoriality and competition (Dray et al. 2006), not to be observed in this study due to relatively large intervals between patches of vegetation surveyed.

Before the statistical analysis, response variables (plant species richness, cover) and explanatory variables (except for canopy cover and spatial variables) were transformed with a logarithmic or exponential function, according to the formulae given by Økland et al. (2001), to improve their normality or at least to remove skewness. Species abundances (expressed on the OTV scale) were Hellinger-transformed. This is recommended by Legendre and Gallagher (2001) to make the data, which normally contain many zero values (due to the presence of many rare species), suitable for Euclidean-based ordination methods such as redundancy analysis (RDA).

\section{Statistical Analysis}

In order to separate the effect of Scots pine encroachment on the heavy-metal grassland vegetation from the effects of other factors, including spatial dependence, we used the variation partitioning approach (Borcard et al. 1992). First, the explanatory variables were grouped into three sets: (1) pine stand parameters (P) comprising canopy cover, age and basal area; (2) abiotic environmental factors (E) comprising SAI and soil properties; and (3) spatial variables (S) comprising the $\mathrm{X}$ and $\mathrm{Y}$ coordinates and $62 \mathrm{PCNMs}$. These sets were separately subjected to forward selection (using $\mathrm{R}$ packfor) to identify variables that significantly explain the variation of plant species composition (in RDA) and species richness (in multiple regression). The forward selection procedure (with 999 random permutations) was based, as recommended by Blanchet et al. (2008), on the 
double stopping criterion: selection stopped when a preselected significance level (here, $\alpha=0.05$ ) was reached or when adjusted $R^{2}\left(R_{\mathrm{a}}^{2}\right)$ computed for the current model after adding another predictor exceeded global $R_{\mathrm{a}}^{2}$ (i.e., for the model involving all explanatory variables).

The P, E and S sets of forward-selected variables were used to decompose the variation in species composition and richness into the following fractions: pure effects of $\mathrm{P}, \mathrm{E}$ and $\mathrm{S}$; their combined effects; and unexplained variation. This was done with the 'varpart' function ( $\mathrm{R}$, 'vegan' library). The calculations were based on $R_{\mathrm{a}}^{2}$ because unadjusted $R^{2}$ values provide biased estimates of the explained variation (Peres-Neto et al. 2006).

To get a better picture of pine-canopy-caused heterogeneity, the three categories of grassland plots (open, partially shaded and deeply shaded) were compared by one-way ANOVA in terms of soil properties and quantitative parameters of vegetation.

All statistical analyses employed $\mathrm{R}$ version 2.13.1 ( $\mathrm{R}$ Development Core Team 2011).

\section{Results}

\section{Habitat Conditions}

The habitat conditions prevailing at the study site are summarized in Table 1. More than half of the plots were on flat or almost flat terrain. Most of the plots sloping more than $5^{\circ}$ had a northern exposure. Northern and southern exposures prevailed. Soil was poorly developed: the A horizon was about $3 \mathrm{~cm}$ thick on average and the sampled topsoil contained large shares of coarse particles (cf. Fig. 2). Soil pH was slightly alkaline and showed very little variation across the study site. Other soil properties varied more but their coefficient of variation $(\mathrm{CV})$ did not exceed $50 \%$ except for water-soluble $\mathrm{Mg}$. The plots differed largely in terms of pine canopy cover: 48 plots were beyond the reach of shade from tree branches and the others were moderately (36 plots) or strongly (40 plots) shaded by canopy (Fig. 2). Pine stand age (determined for $8 \times 8 \mathrm{~m}$ squares) averaged $12 \pm 4$ years (minimum 0, maximum 23; oldest trees established in 1979) and was fairly uniform throughout the study site (CV $23 \%)$. By contrast, stand basal area, averaging $9.8 \pm 8.1 \mathrm{~m}^{2} \cdot \mathrm{ha}^{-1}$ (minimum 0, maximum $52.1)$, showed relatively high variation ( $C V 83 \%)$.
The interpolated values (used in statistical analysis) of both parameters are presented in Table $\mathbf{1}$.

Vegetation Characteristics

We found 56 species of herbaceous vascular plants in the survey. The number of species per plot ranged between 3 and 23 (mean 16 13 ); very few plots were species-poor $(<8$ species per plot; Fig. 2). The most frequent plants were Pimpinella saxifraga (119 plots), Thymus pulegioides (117 plots), Festuca ovina (116 plots), Leontodon hispidus subsp. hastilis (116 plots) and Lotus corniculatus (109 plots). The grassland was composed mainly of plants characteristic of dry grassland and steppe (on average $7 \pm 2$ Festuco-Brometea species per plot, with $15 \pm 10 \%$ total cover), hay meadow and pasture (on average $6 \pm 2$ MolinioArrhenatheretea species per plot, with $13 \pm 10 \%$ total cover), and temperate sand grassland and therophyte sward (on average $2 \pm 1$ Koelerio glaucaeCorynephoretea canescentis species per plot, with $16 \pm$ $17 \%$ total cover). Species typical of other plant communities, including ruderal and forest, seldom occurred. Most plants observed in the study were long-lived: perennial (44) or at least biennial (7). Among these, hemicryptophytes dominated (36). As regards Grime C-S-R strategies (Grime et al. 2007), only C-S-R plants (35) and competitors (10) were numerous. There were 43 forbs, 9 grasses and 4 legumes. The grassland was loose, with total cover not reaching $100 \%$ on any plot (mean $47 \pm 20 \%$, minimum $2 \%$, maximum $98 \%$; Fig. 2). The species that contributed most to total cover were the above-listed most frequent plants, especially Festuca ovina, which dominated in several cases (covering more than $50 \%$ of a plot). There were also seedlings of woody plants in the ground layer (not taken into account in the analysis of species richness and composition). The most frequent (present on 56 plots) and abundant was Pinus sylvestris, and seedlings of Euonymus sp., Juniperus communis and Quercus robur occurred sporadically as single plants. Cover of the bryophyte and lichen layer was low, averaging $10 \pm 15 \%$, and 87 values did not exceed the mean.

\section{Decomposition of Variation in the Plant Community Data}

In RDA, all forward-selected variables (Table 2) accounted for $20.4 \%$ of the variation in plant species 
Table 1 Descriptive statistics for pine stand parameters, SAI and soil properties.

\begin{tabular}{|c|c|c|c|c|c|}
\hline Variable & Unit & Minimum & Median & Mean $\pm S D$ & Maximum \\
\hline Stand age ${ }^{a}$ & years & 7.1 & 11.8 & $12.1 \pm 2.3$ & 19.6 \\
\hline Stand basal area ${ }^{a}$ & $\mathrm{~m}^{2} \cdot \mathrm{ha}^{-1}$ & 4.2 & 9.5 & $9.7 \pm 3.0$ & 16.7 \\
\hline SAI & & -0.71 & 0 & $-0.07 \pm 0.20$ & 0.37 \\
\hline A horizon thickness & $\mathrm{cm}$ & 0.8 & 3.1 & $3.2 \pm 1.3$ & 7.2 \\
\hline Soil fine particles & $\%$ & 23.8 & 58.9 & $59.1 \pm 11.8$ & 85.8 \\
\hline $\mathrm{pH}$ & & 7.3 & 7.7 & $7.7 \pm 0.2$ & 8.2 \\
\hline Total N & $\%$ & 0.11 & 0.33 & $0.35 \pm 0.13$ & 0.81 \\
\hline Olsen P & $\mathrm{mg} \cdot \mathrm{kg}^{-1}$ & 8.1 & 19.1 & $21.0 \pm 10.2$ & 84.6 \\
\hline Water-soluble K & $\mathrm{mg} \cdot \mathrm{kg}^{-1}$ & 25 & 62 & $64 \pm 24$ & 138 \\
\hline Water-soluble $\mathrm{Ca}$ & $\mathrm{mg} \cdot \mathrm{kg}^{-1}$ & 37 & 80 & $89 \pm 41$ & 261 \\
\hline Water-soluble $\mathrm{Mg}$ & $\mathrm{mg} \cdot \mathrm{kg}^{-1}$ & 15 & 34 & $40 \pm 26$ & 199 \\
\hline Water-soluble Zn & $\mathrm{mg} \cdot \mathrm{kg}^{-1}$ & 4.4 & 9.2 & $9.5 \pm 2.9$ & 18.3 \\
\hline Exchangeable K & $\mathrm{mg} \cdot \mathrm{kg}^{-1}$ & 32 & 113 & $120 \pm 44$ & 223 \\
\hline Exchangeable $\mathrm{Ca}$ & $\mathrm{mg} \cdot \mathrm{kg}^{-1}$ & 648 & 2216 & $2228 \pm 752$ & 4661 \\
\hline Exchangeable Mg & $\mathrm{mg} \cdot \mathrm{kg}^{-1}$ & 108 & 395 & $419 \pm 176$ & 1215 \\
\hline Exchangeable Zn & $\mathrm{mg} \cdot \mathrm{kg}^{-1}$ & 33 & 113 & $118 \pm 56$ & 261 \\
\hline
\end{tabular}

${ }^{\text {a }}$ Variables obtained by interpolation (see text for explanation).

composition. Pine stand parameters captured $6.1 \%$, environmental factors captured $9.2 \%$, and spatial variables captured $13.9 \%$ of the variation (Fig. 3). Both the overall and the pure effects of the three explanatory datasets were statistically significant. Pure effects of the pine and spatial components exceeded joint effects. For the environmental component, joint effects, especially those involving the spatial component, predominated.

Table 2 shows that canopy cover was the variable contributing the most to the variability in the species data. It was responsible, together with pine stand age, for the main shift in herbaceous community structure (RDA axis 1; Fig. 4): from dry grassland with lightdemanding species, such as Euphrasia stricta, Gypsophila fastigiata, Plantago lanceolata or Thymus pulegioides, towards assemblages with more shadetolerant species (e.g. Viola rupestris). Other important changes in the plant community occurred along the gradient of soil properties (RDA axis 2; Fig. 4). With decreasing amount of coarse particles in topsoil, increasing A horizon thickness and increasing content of some macronutrients, pioneer species (e.g. Biscutella laevigata, Silene vulgaris) were replaced by species typical of more fertile habitats (e.g. Ranunculus acris, Plantago lanceolata, Carex hirta, Achillea millefolium).
In partial RDA, in which the relevant spatial variables (those from Table 2) were used as covariables, only two variables - canopy cover and soil fine particle fraction - were forward-selected to explain the variability of species data. Since these variables also played the primary roles in the previous RDA (Fig. 4), the compositional response of the plant community revealed by the two analyses was largely the same.

In multiple regression, $34.2 \%$ of the variation of plant species richness was explained by all forwardselected variables (Table 3). The overall effects of the three explanatory datasets were statistically significant (Fig. 3). Stand age (the only pine stand parameter in the analysis) captured $9.6 \%$ of the variation, environmental factors captured $13.3 \%$, and spatial variables captured $28.4 \%$. Pure effects of the spatial and environmental components were relevant whereas the pure effect of the pine component was virtually absent. Joint effects were important when they involved the spatial component.

\section{Differences Between Open and Shaded Plots}

Simple correlation analysis showed that pine canopy cover was related to other parameters of pine stand, i.e., age $(r=0.35, P<0.001)$ and basal area $(r=0.48$, $P<0.001)$. Hence, the differences detected by one-way 
Pine canopy cover

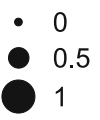

Plant species richness

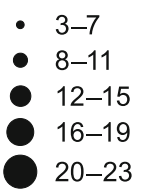

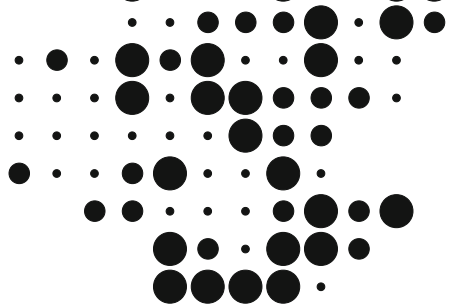

$\bullet \cdot$

$\cdot \cdot 0 \cdot 0$

$\cdot \bullet \cdot \cdot 0$

$.0 \circ \bullet$

$0 \circ 00$

- 0.08

.

$0 \cdot \cdot 0 \cdot 000$

$100 \cdot$
Soil fine particle fraction [\%]

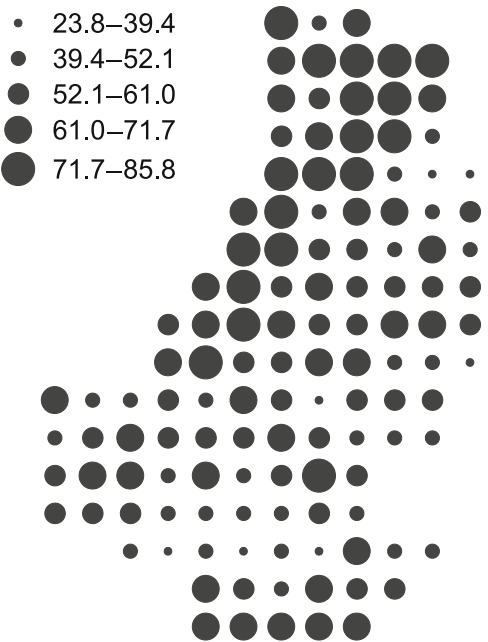

0000
SAI

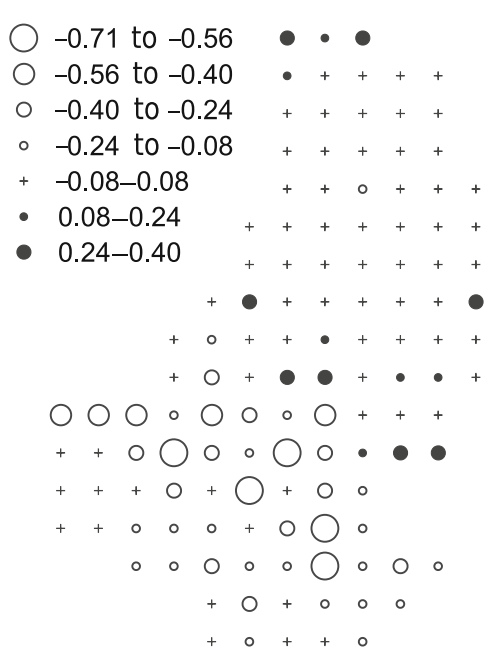

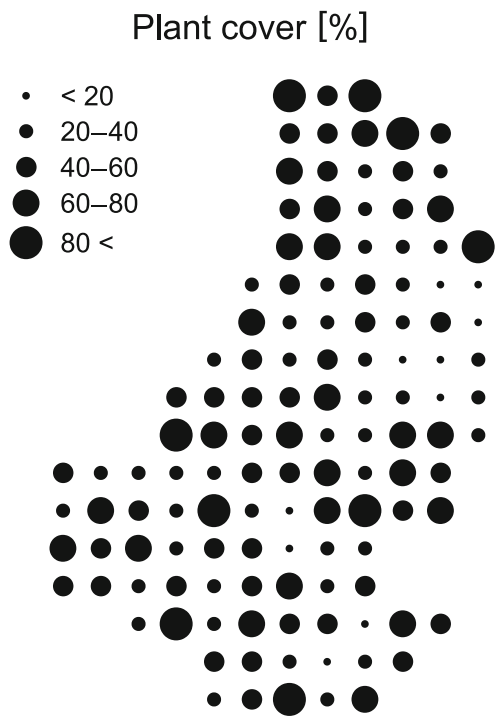

Fig. 2 Maps of selected habitat properties and herbaceous vegetation parameters.

ANOVA between open and shaded plots probably reflected both varying light conditions and duration of pine impact. In one-way ANOVA, A horizon thickness and the content of both water-soluble and extractable $\mathrm{Ca}$ and $\mathrm{Mg}$ were the only soil characteristics differing significantly between shaded and non-shaded plots (Fig. 5): the A horizon was thinner and availability of $\mathrm{Ca}$ and $\mathrm{Mg}$ was higher (data shown only for watersoluble $\mathrm{Ca}$ ) under pine branches than in open plots. The herbaceous vegetation was significantly speciesricher and denser in plots fully exposed to sunlight than in deeply shaded plots (Fig. 5). This pattern was observed for most plant groups (representing different plant traits) examined separately. Opposite trends were also noted (e.g. for competitors or MolinioArrhenatheretea species), but they were not statistically significant in any case (data not shown).

\section{Discussion}

The concentration of heavy metals in soil is one of the strongest determinants of plant community structure (Shaw 1990). Its effect is evident in the grassland we 
Table 2 Variables selected for RDA of species distribution data on the basis of forward selection.

\begin{tabular}{|c|c|c|c|}
\hline \multirow[t]{2}{*}{ Explanatory variable } & \multicolumn{3}{|l|}{ RDA } \\
\hline & $R_{\mathrm{a}}^{2}$ & $F$-ratio & $P$-value \\
\hline \multicolumn{4}{|l|}{ Pine stand } \\
\hline Canopy cover & 0.042 & 6.4 & 0.001 \\
\hline Stand age & 0.010 & 2.3 & 0.002 \\
\hline Stand basal area & 0.009 & 2.2 & 0.003 \\
\hline \multicolumn{4}{|l|}{ Abiotic environment } \\
\hline SAI & 0.025 & 4.1 & 0.001 \\
\hline Exchangeable $\mathrm{Ca}$ & 0.021 & 3.7 & 0.001 \\
\hline Soil fine particles & 0.019 & 3.5 & 0.001 \\
\hline A horizon thickness & 0.008 & 2.0 & 0.004 \\
\hline Water-soluble K & 0.005 & 1.6 & 0.027 \\
\hline $\mathrm{pH}$ & 0.005 & 1.6 & 0.028 \\
\hline Total N & 0.005 & 1.6 & 0.030 \\
\hline Exchangeable Mg & 0.004 & 1.6 & 0.036 \\
\hline \multicolumn{4}{|l|}{ Space } \\
\hline $\mathrm{Y}$ & 0.038 & 5.8 & 0.001 \\
\hline PCNM-4 & 0.025 & 4.3 & 0.001 \\
\hline $\mathrm{X}$ & 0.014 & 2.9 & 0.001 \\
\hline PCNM-5 & 0.014 & 2.9 & 0.001 \\
\hline PCNM-17 & 0.012 & 2.6 & 0.001 \\
\hline PCNM-2 & 0.010 & 2.3 & 0.001 \\
\hline PCNM-7 & 0.006 & 1.8 & 0.007 \\
\hline PCNM-24 & 0.006 & 1.8 & 0.014 \\
\hline PCNM-8 & 0.005 & 1.7 & 0.026 \\
\hline PCNM-15 & 0.005 & 1.6 & 0.021 \\
\hline PCNM-34 & 0.004 & 1.6 & 0.017 \\
\hline
\end{tabular}

Species composition

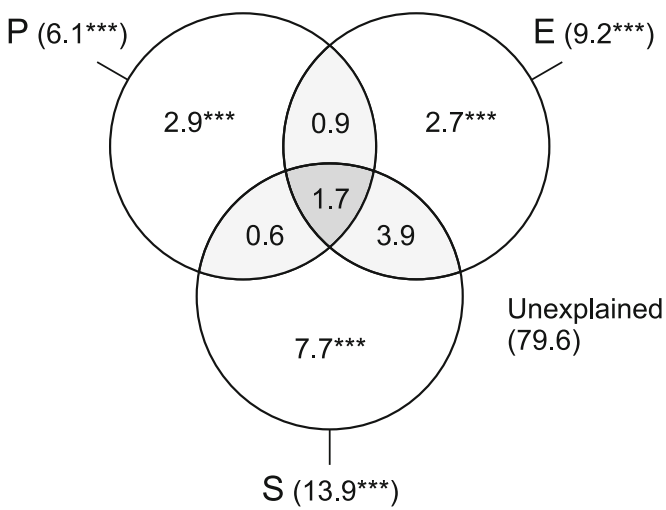

Fig. 3 Venn diagrams partitioning the variation of species composition and species richness between three sets of explanatory variables (adjusted $R^{2}$ in \%): $\mathrm{P}$ - pine stand parameters, $\mathrm{E}$ - abiotic studied; it is composed of plants known for their heavymetal resistance, including Biscutella laevigata, Silene vulgaris, Festuca ovina, Dianthus carthusianorum, Cardaminopsis arenosa (syn.: Arabidopsis arenosa), Armeria maritima and Viola tricolor (Grodzińska and Szarek-Łukaszewska 2009).

Although metal contamination of soil affects the species richness and composition of this grassland, its proxy in our study (water-soluble and exchangeable Zn) presented low explanatory power, probably because of the factor's low spatial variability. The sampling area was small, located entirely on the northern slope of the heap, whose waste material (subsoil) was of the same geological origin and was largely homogenized. As a result, the samples did not differ much in available $\mathrm{Zn}$ concentration or in other soil properties. We did not determine the total content of heavy metals, but data on total $\mathrm{Zn}$ and $\mathrm{Pb}$ collected for this area by Grodzińska and Szarek-Łukaszewska (2009) suggest that it varies very slightly on the heap ( $C V$ ca $25 \%)$.

The grassland community responded negatively to Scots pine encroachment, manifested in a significant reduction of the frequency and abundance of many light-demanding species of different vegetation classes, and in a decrease of total plant species richness and cover. In view of the paucity of detailed reports on early succession of heavy-metal grassland, it is difficult to say whether this result is typical. A few authors mention that these communities can be seriously threatened by spontaneous encroachment of woody vegetation or afforestation (Baker et al. 2010; Baumbach 2012), but they

\section{Species richness}

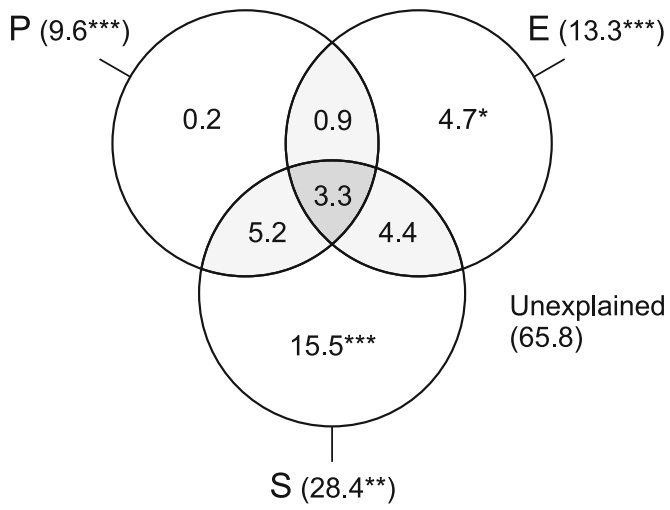

environmental factors, and $\mathrm{S}-$ spatial variables. Significance levels: $*_{-} P<0.05, *_{-}+P<0.01,{ }^{*} * *_{-} P=0.001$. 


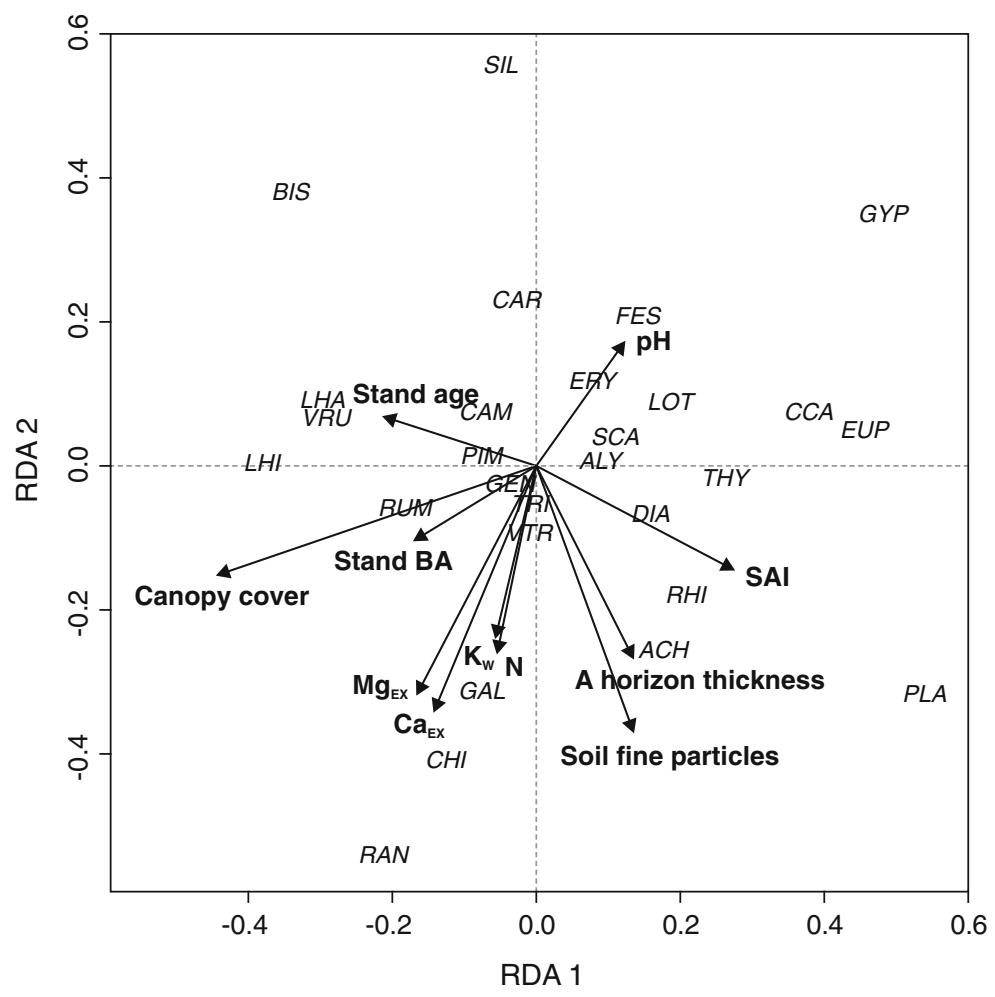

Fig. 4 RDA ordination of plant community data in relation to the best predictors obtained by forward selection (see Table 2). Axis 1 and 2 accounted for 6.3 and $5.2 \%$ of the variation in the data, respectively. For clarity, only species with relevant scores are displayed, using the 'orditorp' function (R, vegan package). Species codes: ACH - Achillea millefolium, ALY - Alyssum montanum, BIS - Biscutella laevigata, CAM - Campanula rotundifolia, CAR - Carlina vulgaris, CCA-Carex caryophyllea, CHI - Carex hirta, DIA - Dianthus carthusianorum, ERY Erysimum odoratum, EUP - Euphrasia stricta, FES - Festuca

provide little information on the dynamics of herbaceous vegetation. Given our results and the scant published evidence, it can be expected that under favourable conditions (e.g. lack of disturbances, availability of seeds of woody plants, insufficient metal toxicity), heavy-metal grasslands will quickly succeed into woodlands, following the pattern described many times for a similar community type - dry grassland (e.g. Rejmének and Rosén 1992; Davies and Waite 1998; Willems and Bik 1998).

The most valuable components of the studied plant community are species that make the Olkusz heavymetal grassland unique: Biscutella laevigata, a local metallophyte (Babst-Kostecka et al. 2014), and Gentianella germanica, whose population has apparently adapted to elevated soil loads of heavy metals (Grześ 2007). They co-occurred with metal-tolerant ovina, GAL - Galium album, GEN - Gentianella germanica, GYP - Gypsophila fastigiata, LHA - Leontodon hispidus subsp. hastilis, LHI - Leontodon hispidus subsp. hispidus, LOT - Lotus corniculatus, PIM - Pimpinella saxifraga, PLA - Plantago lanceolata, RAN - Ranunculus acris, RHI - Rhinanthus minor, RUM - Rumex acetosa, SCA - Scabiosa ochroleuca, SIL - Silene vulgaris, THY - Thymus pulegioides, TRI - Trifolium pratense, $V R U$ - Viola rupestris, VTR - Viola tricolor. Other abbreviations: $\mathrm{BA}$ - basal area, EX - exchangeable, $\mathrm{w}_{\text {- water-soluble. }}$

populations/ecotypes of common dry grassland species such as Silene vulgaris, Leontodon hispidus s.1., Festuca ovina and Potentilla arenaria. All these plants are regarded as remarkable pioneers or at least early successional species. In fact, they grew mostly on very loosely vegetated plots with shallow, skeletal soil, or on bare mining waste rock (see also Wójcik et al. 2014). They are reminiscent of the well known metallophyte communities developed on bedrock material of natural (primary habitats) and anthropogenic (secondary habitats) metalliferous sites (Ernst 1974; Baker and Proctor 1990; Punz and Mucina 1997; Brown 2001; Becker and Brändel 2007).

The aforementioned species are considered light-demanding, often a feature of pioneer plants. In this study, however, they clearly did not respond to the insolation gradient. This was especially true of Biscutella 
Table 3 Variables selected for multiple regression of species richness on the basis of forward selection.

\begin{tabular}{llll}
\hline Explanatory variable & \multicolumn{2}{c}{ Multiple regression } & \\
\cline { 2 - 4 } & $R_{\mathrm{a}}^{2}$ & $F$-ratio & $P$-value \\
\hline Pine stand & & & \\
$\quad$ Stand age & 0.096 & 14.1 & 0.001 \\
Abiotic environment & & & \\
Water-soluble K & 0.036 & 6.0 & 0.012 \\
pH & 0.034 & 5.6 & 0.018 \\
Water-soluble Mg & 0.032 & 5.2 & 0.027 \\
Water-soluble Zn & 0.031 & 4.9 & 0.027 \\
Space & & & \\
PCNM-27 & 0.075 & 11.6 & 0.003 \\
Y & 0.067 & 9.8 & 0.007 \\
PCNM-12 & 0.050 & 8.5 & 0.006 \\
PCNM-14 & 0.048 & 8.5 & 0.010 \\
PCNM-4 & 0.026 & 5.3 & 0.020 \\
PCNM-54 & 0.018 & 4.0 & 0.046 \\
\hline
\end{tabular}

laevigata, Silene vulgaris and Leontodon hispidus s.l., which occurred abundantly both on open plots and on those shaded by pine canopy. Interestingly, this observation is reported from other parts of the OOR area. According to Grodzińska et al. (2010), many grassland species, including metallophytes and metal-tolerant species, can be found, though not in large numbers, in relatively dense 20-40-year-old Scots pine monocultures planted for land rehabilitation directly on mining waste or on metal-polluted soil. The rare Biscutella laevigata and Gentianella germanica are among them. Suitable substrate and the presence of tree canopy gaps enable their survival in these forest habitats. Brown (2001), who surveyed some metalliferous sites in Germany, highlighted the occurrence of Silene vulgarsis in open birch stands, suggesting that this species can tolerate moderate shade.

Scots pine can affect grassland vegetation not only by shading. Pine litter may suppress establishment of certain herb species through physical impediment and release of allelopathic substances (Navarro-Cano et al. 2010). As shown by Xiong and Nilsson (1999), the size of this effect depends on litter depth (or biomass). In this study, the accumulation of pine needles under shaded plots was small $(<1 \mathrm{~cm})$ and, given the findings by Xiong and Nilsson (1999), can be considered a negligible factor. Conifers, as well as some species of deciduous trees, tend to acidify the soil (Finzi et al. 1998; Thelin et al. 1998), which may lead to mobilization of heavy metals accumulated there (Wilson and Bell 1996). We did not observe the action of such a mechanism (no differences in $\mathrm{pH}$ and $\mathrm{Zn}$ availability between open and shaded plots), perhaps due to the recency of the pine invasion. Instead, we recorded increased concentrations of water-soluble and exchangeable $\mathrm{Ca}$ and $\mathrm{Mg}$ under pine canopy. This implicates pines in the provision of some nutrients to the topsoil, for example
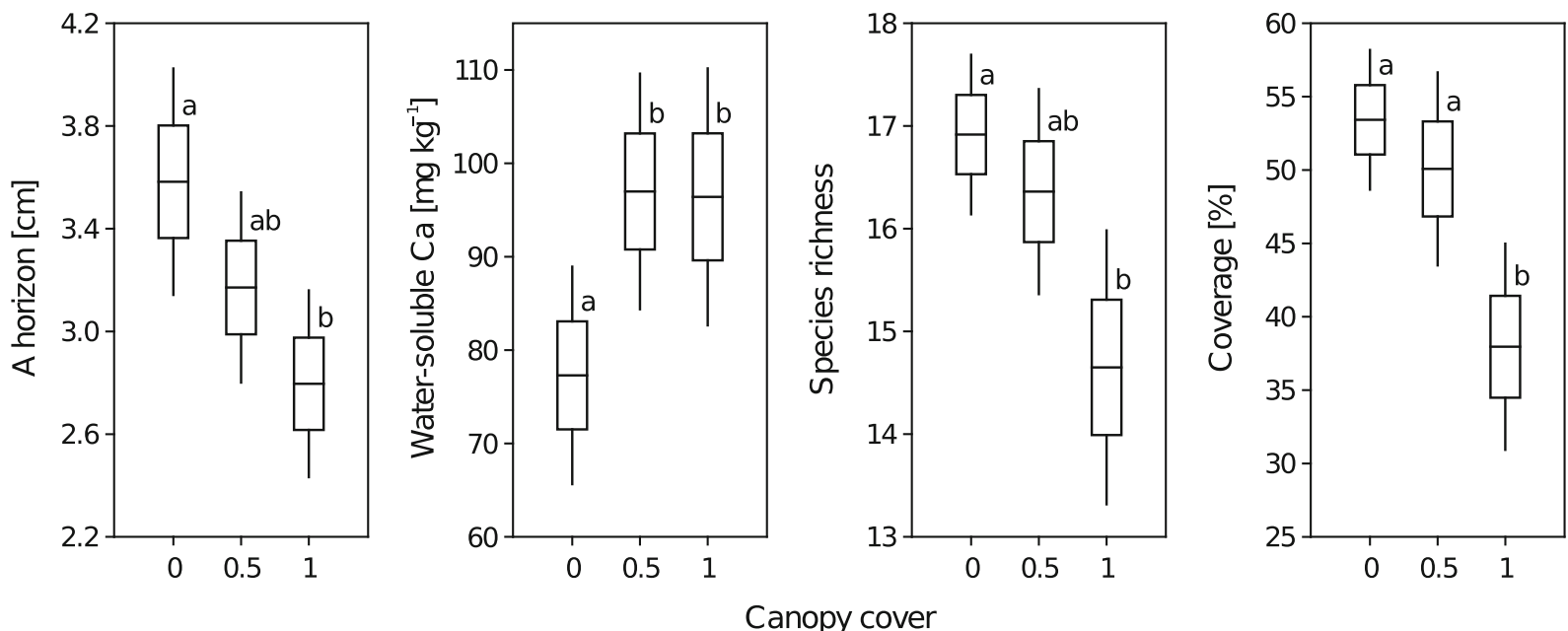

Fig. 5 Comparison of selected vegetation parameters and soil properties between the three canopy cover categories $(0-$ open plots, 0.5 - partially shaded plots, 1 - deeply shaded plots) using

one-way ANOVA. Boxes bearing different letters differ significantly according to Tukey's test $(P<0.05)$. 
in the form of litter fall (Clarholm and Skyllberg 2013). Pine trees also seem to have influenced the topsoil structure. Shading caused a significant decrease of total plant cover, which averaged less than $40 \%$ on deeply shaded plots. This probably resulted in lower accumulation of fine mineral particles and organic matter and/or greater susceptibility of the soil surface to erosion, and finally in a thinner A horizon. According to Hodačová and Prach (2003), who compared reclaimed and spontaneously revegetated spoil heaps after brown coal mining, a dense herb layer protected slopes better against rill erosion than dense tree stands with reduced herb cover. Of course, the negative relationship between soil depth and canopy cover might be the result of Scots pine's tendency to establish and grow in shallow soil rather than deep soil. However, our data did not confirm that. The correlation between the abundance of pine seedlings and A-horizon thickness was insignificant, suggesting that the former explanation is more likely. The adverse impact of pine trees on soil formation process is beneficial to pioneer plants (e.g. Biscutella laevigata, Silene vulgaris); this factor may compensate for unfavourable light conditions.

Variation partitioning showed that the grassland vegetation responded differently to different pine stand parameters. Species composition was determined primarily by canopy cover whereas species richness depended more on stand age. The explanation for this seems straightforward. The effect of pine canopy is apparent as a compositional shift in the community from the very outset of pine encroachment because shading clearly reduces the abundance of some shade-intolerant plants. So long as the pine trees are scattered, however, the reduction of the number of grassland species is negligible even under trees, since the still-extant open patches ensure a steady supply of grassland species seeds. As the stand ages, the open area contracts due to the increasing size and density of trees, and the grassland species lose their microhabitats for reproduction and start to withdraw (cf. Rejmének and Rosén 1992). If this process goes too far, it may be difficult to restore the community to its original state, as shown by many studies of semi-natural grasslands of nonmetalliferous sites (Dzwonko and Loster 1998; Bakker and Berendse 1999; Bisteau and Mahy 2005; Dzwonko and Loster 2007; Piqueray et al. 2011). The difficulty is due mostly to the nature of the grassland soil seed bank, which is essentially transient (Bisteau and Mahy 2005), and to short-range dispersal of the majority of grassland species (Poschlod et al. 1998).
The slope-aspect index (SAI) was among the important explanatory variables of plant species composition. It correlated with many species, including Rumex acetosa, Leontodon hispidus s.1., Campanulla rotundifolia, Biscutella laevigata and Dianthus carthusianorum (negatively), and Plantago lanceolata (positively). Since this index is calculated from slope values, it can reflect the intensity of erosion and thus soil depth. In this study, the index did not correlate with A horizon thickness, nor with soil fine particle fraction. The effect of SAI may therefore be considered in terms of microclimate. As such, it seems to explain the distribution of Biscutella laevigata. This plant is a mountain species (Babst-Kostecka et al. 2014) which only exceptionally occurs in lowland localities. In the studied grassland, it preferred colder and wetter plots, that is, those with a northern exposure; the same was observed by Dobrzańska (1955). Possibly, these plots offered microclimatic conditions most similar to those at higher elevations. As regards other species, further studies are needed to elucidate the potential role of SAI in their distribution.

Most of the variation of plant species composition and richness was not explained. A random component, which tends to be dominant in field studies, obviously was largely responsible for that. It is also possible that some important spatially unstructured predictors were not taken into account in the models. Most of the explained variation was captured by spatial variables and spatial structures present in the pine and environment datasets. The primary role of spatial dependence in shaping the grassland vegetation was likely the effect of the fine spatial scale of the study. Topographical features (slope, aspect, elevation, etc.) sampled on such a scale usually show high spatial autocorrelation. If these features vary considerably over the study area, they will induce - by processes such as erosion, accumulation or runoff - spatial continuity of other environmental characteristics, and consequently of vegetation.

Maintaining the studied grassland's present species richness and composition would require complete removal of the woody vegetation, repeated as needed. For a similar community, a semi-natural calcareous grassland on non-metalliferous soil, Dzwonko and Loster (2007) recommended cutting down the woody vegetation every 5-6 years. To protect plants characteristic of metalliferous substrate, the intervals presumably can be longer because the flagship species, and some accompanying metal-tolerant plants, survive and apparently 
reproduce under pine canopy. On the other hand, these species are sensitive to eutrophication and tend to withdraw from places where fine soil and organic matter completely cover the rocky substrate. Therefore, controlled disturbance of the soil surface, including removal of topsoil or mixing it with subsoil (Baker et al. 2010), should also be incorporated into plans for active management of the site. According to Lucassen et al. (2008), such management not only creates areas of bare soil or subsoil suitable for pioneers, but may also increase the availability of heavy metals, which benefits metallophytes.

Acknowledgements The study was performed under project FM EEA PL0265, supported by a grant from Iceland, Liechtenstein and Norway through the Financial Mechanism of the European Economic Area, and received partial support from statutory funds of the W. Szafer Institute of Botany of the Polish Academy of Sciences. We thank Jan Holeksa for valuable help with field work, Michael Jacobs for line-editing the manuscript for submission, and the staff of the Bolesław Mine and Metallurgical Plant and the authorities of Bolesław and Bukowno municipalities for their kind cooperation.

Open Access This article is distributed under the terms of the Creative Commons Attribution 4.0 International License (http:// creativecommons.org/licenses/by/4.0/), which permits unrestricted use, distribution, and reproduction in any medium, provided you give appropriate credit to the original author(s) and the source, provide a link to the Creative Commons license, and indicate if changes were made.

\section{References}

Babst-Kostecka AA, Parisod C, Godé C, Vollenweider P, Pauwels $M$ (2014) Patterns of genetic divergence among populations of the pseudometallophyte Biscutella laevigata from southern Poland. $\mathrm{Pl} \&$ Soil 383:245-256

Baker AJM, Ernst WHO, van der Ent A, Ginocchio R (2010) Metallophytes: the unique biological resource, its ecology and conservational status in Europe, central Africa and Latin America. In Batty LC, Hallberg KB (eds) Ecology of industrial pollution. Cambridge University Press, Cambridge, pp 7-40

Baker AJM, Proctor J (1990) The influence of cadmium, copper, lead, and zinc on the distribution and evolution of metallophytes in the British Isles. Pl Syst Evol 173:91-108

Bakker JP, Berendse F (1999) Constraints in the restoration of ecological diversity in grassland and heathland communities. Trends Ecol Evol 14:63-68

Baumbach H (2012) Metallophytes and metallicolous vegetation: evolutionary aspects, taxonomic changes and conservational status in Central Europe. In Tiefenbacher J (ed) Perspectives on nature conservation - patterns, pressures and prospects. InTech, Rijeka, pp 93-118
Becker T, Brändel M (2007) Vegetation-environment relationships in a heavy metal-dry grassland complex. Folia Geobot 42 : 11-28.

Bisteau E, Mahy G (2005) Vegetation and seed bank in a calcareous grassland restored from a Pinus forest. Appl Veg Sci 8: 167-174.

Blanchet FG, Legendre P, Borcard D (2008) Forward selection of explanatory variables. Ecology 89:2623-2632

Borcard D, Gillet F, Legendre P (2011) Numerical ecology with R. Springer, New York

Borcard D, Legendre P, Drapeau P (1992) Partialling out the spatial component of ecological variation. Ecology 73 : 1045-1055

Brown G (2001) The heavy-metal vegetation of north-western mainland Europe. Bot Jahrb Syst 123:63-110

Clarholm M, Skyllberg U (2013) Translocation of metals by trees and fungi regulates $\mathrm{pH}$, soil organic matter turnover and nitrogen availability in acidic forest soils. Soil Biol Biochem 63:142-153

Colpaert JV, Wevers JHL, Krznaric E, Adriaensen K (2011) How metal-tolerant ecotypes of ectomycorrhizal fungi protect plants from heavy metal pollution. Ann Forest Sci 68:17-24

Danek M (2007) The influence of industry on Scots pine stands in the south-eastern part of the Silesia-Krakow Upland (Poland) on the basis of dendrochronological analysis. Water Air Soil Pollut 185:265-277

Davies A, Waite S (1998) The persistence of calcareous grassland species in the soil seed bank under developing and established scrub. Pl Ecol 136:27-39

Dickinson NM, Turner AP, Lepp NW (1991) How do trees and other long-lived plants survive in polluted environments? Funct Ecol 5:5-11

Dobrzańska J (1955) Badania florystyczno-ekologiczne nad roślinnością galmanową okolic Bolesławia i Olkusza. Acta Soc Bot Poloniae 24:357-408

Dray S, Legendre P, Peres-Neto PR (2006) Spatial modelling: a comprehensive framework for principal coordinate analysis of neighbour matrices (PCNM). Ecol Modelling 196:483493

Dzwonko Z, Loster S (1998) Dynamics of species richness and composition in a limestone grassland restored after tree cutting. J Veg Sci 9:387-394

Dzwonko Z, Loster S (2007) A functional analysis of vegetation dynamics in abandoned and restored limestone grasslands. $J$ Veg Sci 18:203-212

Ernst W (1974) Schwermetallvegetation der Erde. Gustav Fischer Verlag, Stuttgart

Finzi AC, Canham CD, van Breemen N (1998) Canopy tree-soil interactions within temperate forests: species effects on $\mathrm{pH}$ and cations. Ecol Appl 8:447-454

Grime JP, Hodgson JG, Hunt R (2007) Comparative plant ecology, a functional approach to common British species. Castlepoint Press, Clippenham

Grodzińska K, Szarek-Łukaszewska G (2009) Heavy metal vegetation in the Olkusz region (southern Poland) - preliminary studies. Polish Bot J 54:105-112

Grodzińska K, Szarek-Łukaszewska G, Godzik B (2010) Pine forests of $\mathrm{Zn}-\mathrm{Pb}$ post-mining areas of southern Poland. Polish Bot J 55:229-237

Grześ IM (2007) Does rare Gentianella germanica (Wild.) Börner originating from calamine spoils differ in selected 
morphological traits from reference populations? Plant Spec Biol 22:49-52

Isaaks EH, Srivastava RM (1990) An introduction to applied geostatistics. Oxford University Press, Oxford

ISO (1994) ISO 11260. Soil quality - Determination of the potential cation exchange capacity and exchangeable cations using barium chloride solution. International Organization for Standarization, Geneva

ISO (1995) ISO 11261. Soil quality - Determination of total nitrogen - Modified Kjeldahl method. International Organization for Standarization, Geneva

Kapusta P, Szarek-Łukaszewska G, Stefanowicz AM (2011) Direct and indirect effects of metal contamination on soil biota in a $\mathrm{Zn}-\mathrm{Pb}$ post-mining and smelting area (S Poland). Environm Pollut 159:1516-1522

Legendre P, Dale MRT, Fortin M-J, Gurevitch J, Hohn M, Myers D (2002) The consequences of spatial structure for the design and analysis of ecological field surveys. Ecography 25:601615

Legendre P, Gallagher ED (2001) Ecologically meaningful transformations for ordination of species data. Oecologia 129: 271-280

Lucassen ECHET, Eygensteyn J, Bobbink R, Smolders AJP, van de Riet BP, Kuijpers DJC, Roelofs JGM (2008) The decline of metallophyte vegetation in floodplain grasslands: Implications for conservation and restoration. Appl Veg Sci 12:69-80

Mirek Z, Piękoś-Mirkowa H, Zając A, Zając M (2002) Flowering plants and pteridophytes of Poland. A checklist. W. Szafer Institute of Botany, Polish Academy of Sciences, Kraków

Navarro-Cano JA, Barberá GG, Castillo VM (2010) Pine litter from afforestations hinders the establishment of endemic plants in semiarid scrubby habitats of Natura 2000 network. Restorat Ecol 18:165-169

Nielsen SE, Munro RHM, Bainbridge EL, Stenhouse GB, Boyce MS (2004) Grizzly bears and forestry: II. Distribution of grizzly bear foods in clearcuts of west-central Alberta, Canada. Forest Ecol Managem 199:67-82

Olsen SR, Sommers LE (1982) Phosphorus. In Page AL, Miller RH, Keeney DR (eds) Methods of soil analysis. Part 2. Chemical and microbiological properties. American Society of Agronomy, Madison, pp 403-430
Økland RH, Økland T, Rydgren K (2001) Vegetation-environment relationships of boreal spruce swamp forests in Østmarka Nature Reserve, SE Norway. Sommerfeltia 29:1-190

Peres-Neto PR, Legendre P, Dray S, Borcard D (2006) Variation partitioning of species data matrices: estimation and comparison of fractions. Ecology 87:2614-2625

Piqueray J, Bottin G, Delescaille L-M, Bisteau E, Colinet G, Mahy G (2011) Rapid restoration of a species-rich ecosystem assessed from soil and vegetation indicators: The case of calcareous grasslands restored from forest stands. Ecol Indicators 11:724-733

Poschlod P, Kiefer S, Tränkle U, Fischer S, Bonn S (1998) Plant species richness in calcareous grasslands as affected by dispersability in space and time. Appl Veg Sci 1:75-91

Punz W, Mucina L (1997) Vegetation on anthropogenic metalliferous soils in the Eastern Alps. Folia Geobot 32:283-295

R Development Core Team (2011) R: A language and environment for statistical computing. R Foundation for Statistical Computing, Vienna

Rejmének M, Rosén E (1992) Influence of colonizing shrubs on species-area relationships in alvar plant communities. $J$ Veg Sci 3:625-630

Shaw J (ed) (1990) Heavy metal tolerance in plants: evolutionary aspects. CRC Press, Boca Raton

Thelin G, Rosengren-Brinck U, Nihlgård B, Barkman A (1998) Trends in needle and soil chemistry of Norway spruce and Scots pine stands in South Sweden 1985-1994. Environm Pollut 99:149-158

van der Maarel E (2005) Vegetation ecology - an overview. In van der Maarel E (ed) Vegetation ecology. Blackwell Publishing, Oxford, pp 1-51

Willems JH, Bik LPM (1998) Restoration of high species density in calcareous grassland: the role of seed rain and soil seed bank. Appl Veg Sci 1:91-100

Wilson MJ, Bell N (1996) Acid deposition and heavy metal mobilization. Appl Geochem 11:133-137

Wójcik M, Sugier P, Siebielec G (2014) Metal accumulation strategies in plants spontaneously inhabiting $\mathrm{Zn}-\mathrm{Pb}$ waste deposits. Sci Total Environm 487:313-322

Wóycicki Z (1913) Roślinność terenów galmanowych Bolesławia i Olkusza. Obrazy roślinności królestwa Polskiego 4. Kasa im. Mianowskiego, Warszawa

Xiong S, Nilsson C (1999) The effects of plant litter on vegetation: a meta-analysis. J Ecol 87:984-994 